\title{
Micropropagation of an Exotic Ornamental Plant, Calathea crotalifera, for Production of High Quality Plantlets
}

\author{
Shahril Efzueni Rozali, ${ }^{1,2}$ Kamaludin A. Rashid, ${ }^{2}$ and Rosna Mat Taha ${ }^{1}$ \\ ${ }^{1}$ Institute of Biological Sciences, Faculty of Science, University of Malaya, 50603 Kuala Lumpur, Malaysia \\ ${ }^{2}$ Center for Foundation Studies in Science, University of Malaya, 50603 Kuala Lumpur, Malaysia \\ Correspondence should be addressed to Shahril Efzueni Rozali; shahrilefzueni@yahoo.com
}

Received 10 April 2014; Accepted 18 June 2014; Published 20 July 2014

Academic Editor: Enrique Olmos

Copyright (C) 2014 Shahril Efzueni Rozali et al. This is an open access article distributed under the Creative Commons Attribution License, which permits unrestricted use, distribution, and reproduction in any medium, provided the original work is properly cited.

\begin{abstract}
A successful protocol was established for micropropagation in two selected varieties of exotic ornamental plants, Calathea crotalifera. The effects of different sterilization techniques, explant type, and the combination and concentration of plant growth regulators on shoots induction were studied. The axillary shoot buds explants sprouted from rhizomes in soil free conditions showed high induction rate of shoots with lowest contamination percentage when treated with combination of $30 \%(\mathrm{v} / \mathrm{v}) \mathrm{NaOCl}$, $70 \%(\mathrm{v} / \mathrm{v})$ ethanol, and $0.3 \%(\mathrm{w} / \mathrm{v}) \mathrm{HgCl}_{2}$. In the present study, the highest number of multiple shoots was obtained in MS basal medium supplemented with $3.5 \mathrm{mg} / \mathrm{L}$ 6-Benzylaminopurine (BAP), $1.0 \mathrm{mg} / \mathrm{L}$ 1-Naphthaleneacetic acid (NAA), 3\% sucrose, and $6 \mathrm{~g} / \mathrm{L}$ plant agar for both varieties and was used as multiplication medium. Microshoots were highly induced when the young shoot bud explants were incised longitudinally prior subculture. Chlorophyll analysis was studied to test the effects of activated charcoal and L-glutamine on reduction of necrosis problem. The maximum roots induction was recorded on MS medium supplemented with $1.0 \mathrm{mg} / \mathrm{L}$ 1-Naphthaleneacetic acid (NAA) compared to indolebutyric acid (IBA). The complete regenerated plantlets were successfully acclimatized in the soilless medium under greenhouse condition. This is the first report of rapid mass propagation for C. crotalifera.
\end{abstract}

\section{Introduction}

Calathea crotalifera is one of the important ornamental plants belonging to Marantaceae family. This rhizomatic plant species can produce a very attractive inflorescence and have been used in landscaping especially for screening and indoor plants. The other Calathea sp. has also been used widely in horticulture industry due to its attractive foliar colors and variegation patterns [1]. The exotic appearance of C. crotalifera inflorescence which is known as the rattle shaker flower for the flower's resemblance to a rattlesnake's rattle was making it more popular in cut flower industry. The inflorescence has attractive bracts (modified leafs) that can be found in four different colors which are red, white, green, and yellow with a few conspicuous flowers that will peek out from the bract as they mature. The vase life of the inflorescence can vary greatly like the other exotic tropical ornamentals such as Heliconia sp., Strelitzia sp., and Alpinia sp. [2]. C. crotalifera was traditionally propagated through seeds and by vegetative techniques using the cutting of rhizomes. However, this propagation technique shows very slow growth rate which is lengthy for large-scale multiplication. An efficient multiplication method is required to supply sufficient disease-free plant for large scale cultivation using in vitro propagation. The production of microcuttings with high quality plantlets that are suitable for transplanting into the natural environment was especially in demand. There has been scant information on in vitro propagation of Marantaceae [3, 4]. A few studies on in vitro propagation of Marantaceae have already been reported, for example, Calathea ornata Koern [5], Calathea orbifolia (Linden) Kennedy [1], and Maranta leuconeura cv. Kerchoviana [6]. However, to date, there were no reports on the efficient micropropagation of C. crotalifera which had been performed in the present study. The aim of this study was to develop and establish an aseptic technique in micropropagation method of red and yellow C. crotalifera and to 


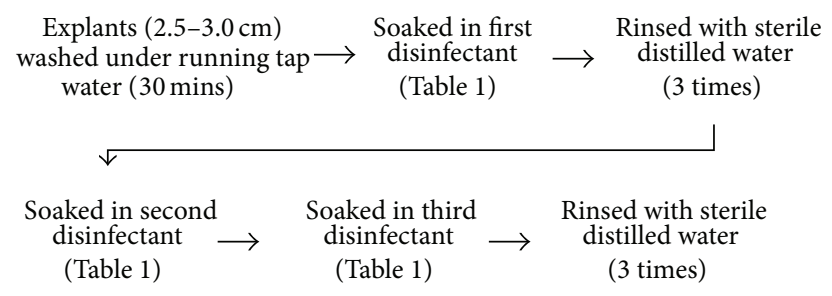

Figure 1: General sterilization method for shoot bud explants of Calathea crotalifera.

induce the formation of multiple shoots and also to produce a high quality regenerated plantlets which can be successfully transferred to the soil.

\section{Materials and Method}

2.1. Establishment of Aseptic Explants. Mature plants of red bract C. Crotalifera (CCR) and yellow bract C. Crotalifera (CCY) were purchased from local farm, Agrobiosolution Company located in Kuantan, Pahang, Malaysia. The plants were maintained at planting area at Centre for Foundation Studies in Science, University of Malaya, under natural condition. Two different sources of young shoot buds were used as explants in this study. The first source of explants is apical young shoot buds obtained directly from the mature plants planted in the soil. The second source of explants was obtained from the sprouting axillary young shoot buds that appeared from the cleaned rhizomes after two weeks under soil free conditions. Suitable explants were collected and washed with detergent under running tap water to remove any soil particles attached to the shoot buds. The external leaves were removed and the shoot buds were trimmed down until the size ranged from 2.5 to $3.0 \mathrm{~cm}$. The explants were then rinsed under running tap water for 30 minutes. Under aseptic conditions, the explants were surface sterilized with three different treatments as shown in Table 1 by following the general sterilization method summarized in Figure 1. Each disinfectant (30\% sodium hypochlorite, $\mathrm{NaOCl}, 70 \%$ ethanol, and mercury chloride, $\mathrm{HgCl}_{2}$ ) was added together with two to three drops of Tween-20 to reduce surface tension. The surface sterilized explants had their external leaves removed and were finally dried on filter papers in the laminar flow air chamber prior to inoculation on media. The contamination, necrotic, and survival percentages of cultures were determined as in Sundram [7].

\subsection{Determination of Culture Media for Multiple Shoots} Induction. The surface sterilized shoot buds explants were trimmed down until the size ranged from 1.0 to $1.5 \mathrm{~cm}$. They were then inoculated on a MS [8] basal medium containing $30.0 \mathrm{~g} \mathrm{~L}^{-1}$ sucrose with different concentrations of plant agar and combinations of plant growth regulators (Tables 2 , 3 , and 4). Axillary shoot bud explants were used in the study on effects of different agar concentrations on shoot production. The explants were inoculated on MS medium supplemented with $3.0 \mathrm{mg} / \mathrm{L}$ BAP and $1.0 \mathrm{mg} / \mathrm{L}$ NAA. Media were adjusted to $\mathrm{pH} 5.8$ prior to autoclave at $121^{\circ} \mathrm{C}$ for 15 minutes. The cultures were maintained in the growth room with $16 / 8 \mathrm{~h}$ photoperiod at $25 \pm 2^{\circ} \mathrm{C}$. In the present study, 10 replicates were used and subculturing was carried out at an interval of eight to twelve weeks. All cultures were examined periodically and the morphological changes were recorded after six weeks of cultures. The effects of different media treatments were determined and quantified based on the percentage of explants showing response for multiple shoots induction. The new shoots produced were used and subcultured for the next subsequent experiments.

\subsection{Effect of Apex Damage to Induce Microshoots Formation.} The effects of apex damage on induction of microshoots were determined based on the method suggested by Nathan et al. [9] and Podwyszyńska [5]. The three months in vitro shoot of CCR and CCY that have been induced in the multiplication media was used. Two techniques of apical dominance elimination were applied in the present study. The first shoot was incised horizontally about $0.5-1.0 \mathrm{~cm}$ over a shoot base whereas the second shoot was incised by halving the buds longitudinally. These explants were then subcultured on the optimum multiplication media. The cultures were incubated under the same culture condition and the data were recorded and analysed in the same manner.

2.4. Effects of Glutamine and Activated Charcoal on Production of High Quality Plantlets. According to the obtained results for multiplication shoots induction in the first study, most of the plantlets showed the presence of necrotic and hyperhydricity leaves. Addition of different concentrations of glutamine and activated charcoal in the growing media (Table 6) was used to improve the shoot quality with low percentage of necrotic leaves. The three months in vitro shoot of CCY was used and the shoot was incised prior to culture in the different media treatments. The data was collected after two months cultured and analyzed based on the percentage of necrotic leaves and concentration of chlorophyll pigments in the leave. Method for pigment identification proposed by Slatnar et al. [10] with a few modifications was used in the present study. For chlorophyll pigment analysis, leaf disc with $1 \mathrm{~cm}^{2}$ area was mashed in $1 \mathrm{~mL}$ DMSO with addition of calcium carbonate powder in the $1.5 \mathrm{~mL}$ microtube. The extracts were incubated in the water bath for 2 hours at $60^{\circ} \mathrm{C}$ prior to centrifugation for 5 minutes at $5000 \mathrm{~g}$. The collected supernatant was then finally analyzed using UVspectrophotometer at $648 \mathrm{~nm}(\mathrm{Ch} \mathrm{b}), 666 \mathrm{~nm}(\mathrm{Ch} \mathrm{a})$, and $480 \mathrm{~nm}$ (carotenoid). The concentration of each pigment was calculated using Wellburn Equation [11].

2.5. Effects of Auxins on Roots Induction. In vitro shoots of yellow CCY from six months old stock cultures were used for in vitro roots induction. Shoots were separated from their clumps and cultured individually in full strength MS medium containing $30.0 \mathrm{~g} \mathrm{~L}^{-1}$ sucrose and augmented with different concentrations of IBA or NAA at 0.0, 0.1, 0.5, 1.0, and $1.5 \mathrm{mg} \mathrm{L}^{-1}$ which added separately (Table 8 ). The medium was adjusted to $\mathrm{pH} 5.8$ and solidified with $6.0 \mathrm{~g} \mathrm{~L}^{-1}$ plant agar. The effects of auxin were determined by measuring the root length, root diameter, and root number of each treatment after 60 days of incubation. 
TABLE 1: Three different treatments in surface sterilization for shoot bud explants of C. crotalifera.

\begin{tabular}{lccc}
\hline Disinfectant & Treatment 1 (T1) & Treatment 2 (T2) & Treatment 3 (T3) \\
\hline First disinfectant (v/v) & $30 \% \mathrm{NaOCl}(15$ minutes) & $30 \% \mathrm{NaOCl}(15$ minutes $)$ & $30 \% \mathrm{NaOCl}(15 \mathrm{minutes})$ \\
Second disinfectant $(\mathrm{v} / \mathrm{v})$ & $30 \% \mathrm{NaOCl}(10$ minutes $)$ & $70 \%$ ethanol (1 minute) & $70 \%$ ethanol (1 minute) \\
Third disinfectant (w/v) & $70 \%$ ethanol (1 minute) & $0.1 \% \mathrm{HgCl}_{2}$ (10 minutes) & $0.3 \% \mathrm{HgCl}_{2}(10 \mathrm{minutes})$ \\
\hline
\end{tabular}

TABLE 2: Effects of different agar concentrations on shoot production of C. crotalifera (CCR and CCY).

\begin{tabular}{lccccc}
\hline \multirow{2}{*}{ Concentration of plant agar $(\mathrm{g} / \mathrm{L})$} & \multicolumn{2}{c}{ Number of shoots } & \multicolumn{2}{c}{ Height of shoot $(\mathrm{cm})$} & \multirow{2}{*}{ Overall observation } \\
& CCY & CCR & CCY & CCR & \\
\hline 3.00 & $1.00 \pm 0.0^{\mathrm{a}}$ & $1.00 \pm 0.0^{\mathrm{a}}$ & $1.96 \pm 0.19^{\mathrm{a}}$ & $1.80 \pm 0.12^{\mathrm{a}}$ & Swollen with vitrified shoot \\
6.00 & $1.80 \pm 0.37^{\mathrm{b}}$ & $1.90 \pm 0.24^{\mathrm{b}}$ & $3.48 \pm 0.14^{\mathrm{b}}$ & $3.44 \pm 0.10^{\mathrm{b}}$ & Swollen with green shoot \\
8.00 & $1.00 \pm 0.0^{\mathrm{a}}$ & $1.00 \pm 0.0^{\mathrm{a}}$ & $2.30 \pm 0.13^{\mathrm{a}}$ & $2.00 \pm 0.16^{\mathrm{a}}$ & Swollen with browning shoot \\
\hline
\end{tabular}

Mean \pm SE, $n=10$. Different letters indicate significant differences between media at $P=0.05$.

TABLE 3: Effects of different concentrations and combinations of cytokinin and auxin on shoot production from two different sources of explants in yellow C. Crotalifera (CCY).

\begin{tabular}{|c|c|c|c|c|c|c|c|c|}
\hline \multirow{2}{*}{ BAP (mg/L) } & \multirow{2}{*}{ Kinetin (mg/L) } & \multirow{2}{*}{ NAA (mg/L) } & \multicolumn{2}{|c|}{ Number of shoots } & \multicolumn{2}{|c|}{ Height of shoot $(\mathrm{cm})$} & \multicolumn{2}{|c|}{ Percentage of leaf (\%) } \\
\hline & & & Apical & Axillary & Apical & Axillary & Apical & Axillary \\
\hline 2.5 & - & 0.5 & $0.70 \pm 0.19^{\mathrm{ab}}$ & $1.80 \pm 0.37^{\mathrm{a}}$ & $1.82 \pm 0.18^{\mathrm{A}}$ & $2.04 \pm 0.15^{\mathrm{A}}$ & $0.00^{\mathrm{a}}$ & $79.70^{\mathrm{a}}$ \\
\hline 2.5 & - & 1.0 & $1.40 \pm 0.24^{\mathrm{abcde}}$ & $2.40 \pm 0.40^{\mathrm{abc}}$ & $2.11 \pm 0.11^{\mathrm{B}}$ & $2.32 \pm 0.04^{\mathrm{AB}}$ & $0.00^{\mathrm{a}}$ & $83.10^{\mathrm{a}}$ \\
\hline 3.0 & - & 0.0 & $2.20 \pm 0.37^{\mathrm{defg}}$ & $3.40 \pm 0.24^{\mathrm{abcd}}$ & $2.08 \pm 0.18^{\mathrm{B}}$ & $3.35 \pm 0.02^{\mathrm{DE}}$ & $0.00^{\mathrm{a}}$ & $83.36^{\mathrm{a}}$ \\
\hline 3.0 & - & 0.5 & $2.00 \pm 0.44^{\operatorname{defg}}$ & $3.40 \pm 0.24^{\mathrm{abcd}}$ & $2.11 \pm 0.06^{\mathrm{B}}$ & $3.21 \pm 0.04^{\mathrm{DE}}$ & $0.00^{\mathrm{a}}$ & $81.00^{\mathrm{a}}$ \\
\hline 3.0 & - & 1.0 & $1.80 \pm 0.58^{\text {cdefg }}$ & $3.60 \pm 0.24^{\mathrm{bcd}}$ & $2.19 \pm 0.07^{\mathrm{BC}}$ & $3.51 \pm 0.04^{\mathrm{E}}$ & $6.80^{\mathrm{c}}$ & $92.54^{\mathrm{bc}}$ \\
\hline 3.5 & - & 0.0 & $2.40 \pm 0.58^{\mathrm{efg}}$ & $3.60 \pm 0.51^{\mathrm{bcd}}$ & $2.21 \pm 0.03^{\mathrm{BC}}$ & $3.60 \pm 0.15^{\mathrm{E}}$ & $9.70^{\mathrm{d}}$ & $99.60^{\mathrm{e}}$ \\
\hline 3.5 & - & 0.5 & $2.60 \pm 0.24^{\mathrm{ef}}$ & $4.00 \pm 0.45^{\mathrm{cd}}$ & $2.32 \pm 0.04^{\mathrm{BC}}$ & $4.46 \pm 0.06^{\mathrm{F}}$ & $4.24^{\mathrm{b}}$ & $100.00^{\mathrm{e}}$ \\
\hline 3.5 & - & 1.0 & $2.80 \pm 0.20^{\mathrm{f}}$ & $5.60 \pm 0.51^{\mathrm{e}}$ & $2.40 \pm 0.04^{\mathrm{C}}$ & $5.44 \pm 0.06^{\mathrm{G}}$ & $4.10^{\mathrm{b}}$ & $97.90^{\mathrm{de}}$ \\
\hline 4.0 & - & 1.0 & $1.80 \pm 0.20^{\text {cdefg }}$ & $4.40 \pm 0.24^{\mathrm{de}}$ & $2.18 \pm 0.05^{\mathrm{BC}}$ & $4.68 \pm 0.10^{\mathrm{F}}$ & $0.00^{\mathrm{a}}$ & $94.00^{\mathrm{bcd}}$ \\
\hline 5.0 & - & 1.0 & $0.80 \pm 0.37^{\mathrm{abc}}$ & $3.40 \pm 0.51^{\mathrm{abcd}}$ & $2.30 \pm 0.04^{\mathrm{BC}}$ & $3.25 \pm 0.09^{\mathrm{DE}}$ & $0.00^{\mathrm{a}}$ & $83.00^{\mathrm{a}}$ \\
\hline 6.0 & - & 1.0 & $0.40 \pm 0.24^{\mathrm{a}}$ & $2.00 \pm 0.84^{\mathrm{ab}}$ & $2.25 \pm 0.04^{\mathrm{BC}}$ & $2.61 \pm 0.14^{\mathrm{BC}}$ & $0.00^{\mathrm{a}}$ & $81.10^{\mathrm{a}}$ \\
\hline- & 1.5 & 1.0 & $1.20 \pm 0.37^{\mathrm{abcd}}$ & $2.20 \pm 0.86^{\mathrm{ab}}$ & $2.24 \pm 0.04^{\mathrm{BC}}$ & $3.20 \pm 0.31^{\mathrm{DE}}$ & $0.00^{\mathrm{a}}$ & $83.20^{\mathrm{a}}$ \\
\hline- & 2.5 & 1.0 & $1.40 \pm 0.24^{\mathrm{abcde}}$ & $2.60 \pm 0.51^{\mathrm{abc}}$ & $2.25 \pm 0.02^{\mathrm{BC}}$ & $3.50 \pm 0.42^{\mathrm{E}}$ & $0.00^{\mathrm{a}}$ & $81.80^{\mathrm{a}}$ \\
\hline- & 3.5 & 1.0 & $1.60 \pm 0.24^{\text {bcdef }}$ & $2.80 \pm 0.58^{\mathrm{abcd}}$ & $2.31 \pm 0.03^{\mathrm{BC}}$ & $2.90 \pm 0.29^{\mathrm{DE}}$ & $0.00^{\mathrm{a}}$ & $96.10^{\text {cde }}$ \\
\hline- & 4.5 & 1.0 & $1.60 \pm 0.24^{\mathrm{bcdef}}$ & $3.40 \pm 0.51^{\mathrm{abcd}}$ & $2.26 \pm 0.04^{\mathrm{BC}}$ & $3.68 \pm 0.14^{\mathrm{E}}$ & $0.00^{\mathrm{a}}$ & $91.10^{\mathrm{b}}$ \\
\hline
\end{tabular}

Mean \pm SE, $n=10$. Different letters indicate significant differences between media at $P=0.05$.

2.6. Acclimatization and Morphological Development of Leaf Surface. Complete plantlets with high quality shoots and roots (Figures $4(\mathrm{~g})$ and $4(\mathrm{~h})$ ) were removed from the rooting medium and the roots were carefully cleaned under running tap water to remove the residual agar. Each plantlet was then transplanted into plastic pots containing mixture of black soil, river sand, coconut husk, and vermiculite $(4: 2: 2: 1)$. The plantlets were then allowed to grow for two months under greenhouse conditions at $25 \pm 2^{\circ} \mathrm{C}$ with direct sunlight for $12 \mathrm{~h}$ daily. Each pot was watered with distilled water for everyday and was covered with transparent plastic which was gradually removed. The morphology of leaf stomata from two months acclimatized plantlets were examined under scanning electron microscope (SEM). The leaf disc with
$0.25 \mathrm{~cm}^{2}$ area from the in vitro and in vivo grown plantlets was used to compare the morphological development of the leaf surface and leaf stomata from two different conditions. The samples were fixed in $2 \%$ aqueous osmium tetroxide, $\mathrm{OsO}_{4}$ for overnight at $4^{\circ} \mathrm{C}$. The treated samples were rinsed with distilled water for two times at 15 minutes each prior to dehydration through ethanol series $(10,20,30,40,50,60,70$, $80,95$, and $100 \%)$. The samples were then infiltrated through ethanol, acetone mixture at 15 minutes each, and ended with pure acetone for 1 hour before dried using a Critical Point $\mathrm{CO}_{2}$ Dryer. The samples were finally viewed under SEM after being gold coated. The presence of wax and morphological development of stomata aperture on the abaxial and adaxial leaf surfaces were observed and recorded. 
TABLE 4: Effects of different concentrations and combinations of cytokinin and auxin on shoot production from two different sources of explants in red C. Crotalifera (CCR).

\begin{tabular}{|c|c|c|c|c|c|c|c|c|}
\hline \multirow{2}{*}{$\mathrm{BAP}(\mathrm{mg} / \mathrm{L})$} & \multirow{2}{*}{ Kinetin (mg/L) } & \multirow{2}{*}{ NAA (mg/L) } & \multicolumn{2}{|c|}{ Number of shoots } & \multicolumn{2}{|c|}{ Height of shoot $(\mathrm{cm})$} & \multicolumn{2}{|c|}{ Percentage of leaf (\%) } \\
\hline & & & Apical & Axillary & Apical & Axillary & Apical & Axillary \\
\hline 2.5 & - & 0.5 & $1.00 \pm 0.00^{\mathrm{abc}}$ & $1.80 \pm 0.20^{\mathrm{a}}$ & $1.80 \pm 0.20^{\mathrm{A}}$ & $2.13 \pm 0.03^{\mathrm{A}}$ & $0.00^{\mathrm{a}}$ & $81.10^{\mathrm{a}}$ \\
\hline 2.5 & - & 1.0 & $1.00 \pm 0.00^{\mathrm{abc}}$ & $2.20 \pm 0.20^{\mathrm{a}}$ & $1.90 \pm 0.11^{\mathrm{AB}}$ & $2.25 \pm 0.02^{\mathrm{AB}}$ & $0.00^{\mathrm{a}}$ & $83.10^{\mathrm{ab}}$ \\
\hline 3.0 & - & 0.0 & $0.90 \pm 0.24^{\mathrm{abc}}$ & $2.00 \pm 0.00^{\mathrm{a}}$ & $2.22 \pm 0.09^{\mathrm{CDEF}}$ & $3.64 \pm 0.10^{\mathrm{D}}$ & $4.30^{\mathrm{b}}$ & $83.36^{\mathrm{ab}}$ \\
\hline 3.0 & - & 0.5 & $1.20 \pm 0.37^{\mathrm{abcd}}$ & $2.40 \pm 0.40^{\mathrm{a}}$ & $2.11 \pm 0.03^{\mathrm{BCDE}}$ & $3.63 \pm 0.10^{\mathrm{D}}$ & $0.00^{\mathrm{a}}$ & $83.66^{\mathrm{ab}}$ \\
\hline 3.0 & - & 1.0 & $1.20 \pm 0.37^{\mathrm{abcd}}$ & $2.20 \pm 0.37^{\mathrm{a}}$ & $2.31 \pm 0.08^{\mathrm{DEF}}$ & $4.47 \pm 0.16^{\mathrm{E}}$ & $6.80^{\mathrm{c}}$ & $91.54^{\mathrm{cd}}$ \\
\hline 3.5 & - & 0.0 & $1.60 \pm 0.24^{\mathrm{cd}}$ & $3.60 \pm 0.40^{b c}$ & $2.28 \pm 0.07^{\mathrm{DEF}}$ & $4.49 \pm 0.23^{\mathrm{E}}$ & $9.70^{\mathrm{d}}$ & $99.60^{\mathrm{f}}$ \\
\hline 3.5 & - & 0.5 & $1.60 \pm 0.24^{\mathrm{cd}}$ & $3.80 \pm 0.37^{b c}$ & $2.35 \pm 0.05^{\mathrm{EF}}$ & $4.63 \pm 0.17^{\mathrm{EF}}$ & $4.74^{\mathrm{b}}$ & $100.00^{\mathrm{f}}$ \\
\hline 3.5 & - & 1.0 & $2.00 \pm 0.32^{\mathrm{d}}$ & $4.40 \pm 0.24^{\mathrm{c}}$ & $2.40 \pm 0.04^{\mathrm{F}}$ & $4.85 \pm 0.12^{\mathrm{F}}$ & $4.30^{\mathrm{b}}$ & $98.80^{\text {ef }}$ \\
\hline 4.0 & - & 1.0 & $1.40 \pm 0.24^{\mathrm{bcd}}$ & $3.40 \pm 0.51^{\mathrm{b}}$ & $2.04 \pm 0.05^{\mathrm{ABCD}}$ & $3.06 \pm 0.16^{\mathrm{C}}$ & $0.00^{\mathrm{a}}$ & $93.70^{\text {de }}$ \\
\hline 5.0 & - & 1.0 & $0.60 \pm 0.24^{\mathrm{ab}}$ & $2.00 \pm 0.32^{\mathrm{a}}$ & $1.99 \pm 0.06^{\mathrm{ABC}}$ & $3.24 \pm 0.07^{\mathrm{C}}$ & $0.00^{\mathrm{a}}$ & $83.00^{\mathrm{ab}}$ \\
\hline 6.0 & - & 1.0 & $0.40 \pm 0.24^{\mathrm{a}}$ & $1.60 \pm 0.24^{\mathrm{a}}$ & $1.96 \pm 0.12^{\mathrm{ABC}}$ & $2.31 \pm 0.06^{\mathrm{AB}}$ & $0.00^{\mathrm{a}}$ & $81.10^{\mathrm{a}}$ \\
\hline- & 1.5 & 1.0 & $1.20 \pm 0.20^{\mathrm{abcd}}$ & $2.00 \pm 0.00^{\mathrm{a}}$ & $2.07 \pm 0.04^{\mathrm{ABCD}}$ & $3.16 \pm 0.05^{\mathrm{C}}$ & $0.00^{\mathrm{a}}$ & $83.26^{\mathrm{ab}}$ \\
\hline - & 2.5 & 1.0 & $1.40 \pm 0.24^{\mathrm{bcd}}$ & $2.00 \pm 0.32^{\mathrm{a}}$ & $2.04 \pm 0.04^{\mathrm{ABCD}}$ & $3.22 \pm 0.03^{\mathrm{C}}$ & $0.00^{\mathrm{a}}$ & $81.86^{\mathrm{a}}$ \\
\hline- & 3.5 & 1.0 & $0.60 \pm 0.24^{\mathrm{ab}}$ & $1.80 \pm 0.37^{\mathrm{a}}$ & $2.16 \pm 0.05^{\mathrm{BCDEF}}$ & $2.56 \pm 0.12^{\mathrm{B}}$ & $0.00^{\mathrm{a}}$ & $85.00^{\mathrm{ab}}$ \\
\hline - & 4.5 & 1.0 & $1.40 \pm 0.24^{\mathrm{bcd}}$ & $1.80 \pm 0.20^{\mathrm{a}}$ & $2.09 \pm 0.06^{\mathrm{BCDE}}$ & $3.19 \pm 0.12^{\mathrm{C}}$ & $0.00^{\mathrm{a}}$ & $88.10^{\mathrm{bc}}$ \\
\hline
\end{tabular}

Mean \pm SE, $n=10$. Different letters indicate significant differences between media at $P=0.05$.

\section{Statistical Analysis}

The data collected were analyzed by one way ANOVA and the mean values \pm SE were subjected to statistical analysis using Duncan's multiple range test (DMRT) at 5\% significance level.

\section{Results and Discussion}

4.1. Establishment of Aseptic Explants. Two different types of young shoot bud explants were used in this study, which are apical shoot bud from soil medium and axillary shoot bud from soilless medium. Both of these explants were surface sterilized using the same protocol based on Figure 1 and Table 1, respectively. In the present study, axillary shoot buds showed the lowest percentage of contamination (25\%) when compared to apical shoot buds (60\%). Thus, comparison of the effectiveness in three different surface sterilization treatments (T1, T2, and T3) on axillary shoot bud explants was used in this study. The best treatment of surface sterilization was achieved when $30 \% \mathrm{NaOCl}, 70 \%$ ethanol, and $0.3 \% \mathrm{HgCl}_{2}$ were utilized in $\mathrm{T} 3$ with the lowest percentage of contamination $(25 \pm 5 \%)$ compared to $\mathrm{T} 1$ and T2. Furthermore, percentage of surviving explants was higher in T3 $(90 \pm 6 \%)$ followed by T2 and T1 even though the percentage of necrotic leaf in T3 is higher compared to other treatments. Most of the contamination is caused by bacteria and no fungi infections were found. Establishment of con tamination free cultures was a major task since the explants were taken from the underground rhizomes [12]. The using of axillary bud that initially sprouted in soil free condition can actually reduce the potential of the explants to be infected by the soil bacteria. This method has been used widely in micropropagation of other rhizomatic species like Heliconia psittacorum [9], Boesenbergia rotunda L. [13], and Curcuma mangga [7]. Disinfecting with 70\% ethanol prior to soaking in $\mathrm{HgCl}_{2}$ enhances the contact between $\mathrm{HgCl}_{2}$ and the surface of explants efficiently. Smith [14] reported that mercury ions in $\mathrm{HgCl}_{2}$ solution can break the structure of the cell membrane and the cytoplasm constituents of pathogenic microorganisms by interfering the enzymes and also the protein molecules. The concentration of $\mathrm{HgCl}_{2}$ was not increased more than $0.3 \%$ as in $\mathrm{T} 3$ because the high concentration of $\mathrm{HgCl}_{2}$ is phytotoxic to plant cells [7]. Based on the results, $\mathrm{T} 3$ was the most effective method with the highest survival rate (Figure 2) after four weeks of cultured. This treatment was therefore applied for subsequent experiments.

4.2. Effects of Medium Solidification on Shoot Induction. The using of different concentrations of agar $(0.3 \%, 0.6 \%$, and $0.8 \%$ ) had showed significant effects on shoot production as shown in Table 2 after eight weeks of culture. The number and height of shoot produced in media augmented with $3.0 \mathrm{~g} / \mathrm{L}$ and $8.0 \mathrm{~g} / \mathrm{Lg}$ of plant agar was lower for both species of C. crotalifera. Development of the shoots produced in these respective media was not in good condition which showed vitrification and browning problem as shown in Figure 3. The best concentration of plant agar for shoot induction in the present study was $6.0 \mathrm{~g} / \mathrm{L}$ and this concentration was used in the next multiplication media. The similar application has been reported in induction of shoot of Maranta leuconeura cv. Kerchoviana on medium augmented with $6 \mathrm{~g} / \mathrm{L}$ plant agar [6]. Vitrified leaves observed in the present study were caused by high relative humidity [15] and can be reduced 


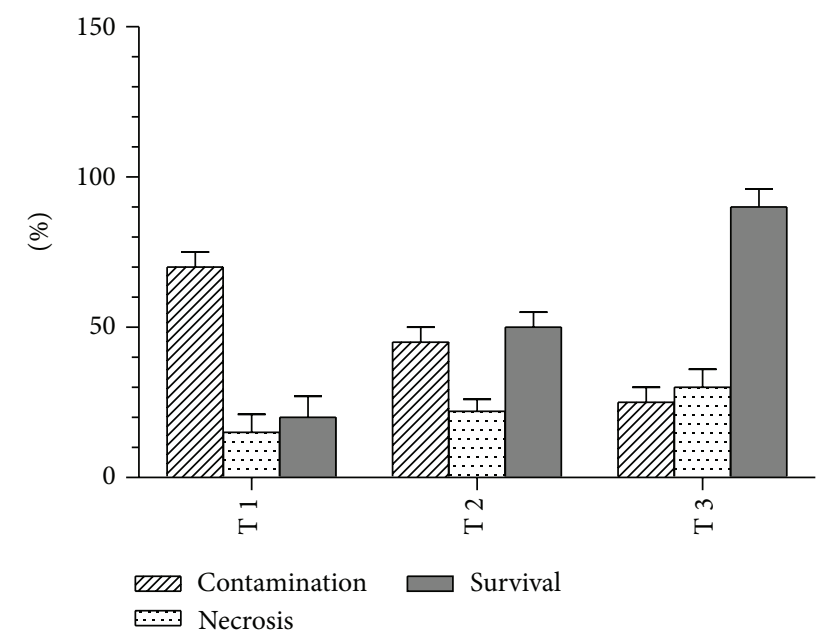

Figure 2: Percentage of surviving explants under different treatments in surface sterilization.

using high concentration of gelling agents [16]. Kataeva et al. [17] reported that the vitrification problem has been correlated to water availability, microelements, and hormonal imbalance in the tissue culture medium. Vitrification or well known as hyperhydricity is a morphological, anatomical, and physiological malformation that makes the plant tissue waterswollen [18] and the in vitro plantlets will have poor epicuticular wax production [19].

\subsection{Effects of Cytokinin and Auxin on Shoot Organogenesis} from Two Different Types of Explants. In general, in vitro culture of apical and axillary shoot bud explants on MS medium supplemented with auxin and cytokinin started to swell up after two weeks of culture. Tables 3 and 4 show the effect of different concentrations and combinations of NAA, BAP, and Kinetin on shoots organogenesis from two different types of explants. Shoot organogenesis from axillary shoot bud explants was faster (within four weeks) compared to apical shoot bud explants (after eight weeks). The different of this growth rate caused the shoots produced from axillary shoot buds explants were higher compared to apical shoot bud explants in both varieties, CCY and CCR after two months culture. Similar result was obtained in rapid multiplication of Boesenbergia rotunda L. by using sprouted axillary bud as initial explants [13]. Based on both results, the production of shoot was increased as the concentration of BAP and Kinetin was increased. However, the number of shoot productions was reduced when the concentration of BAP was higher than $3.5 \mathrm{mg} / \mathrm{L}$. The highest number of shoot productions in CCY $(5.60 \pm 0.51)$ and CCR $(4.40 \pm 0.24)$ was obtained from axillary shoot bud explants in MS medium supplemented with $3.5 \mathrm{mg} / \mathrm{L} \mathrm{BAP}$ and $1.0 \mathrm{mg} / \mathrm{L}$ NAA with highest height of shoot, $5.44 \pm 0.06 \mathrm{~cm}$ and $4.85 \pm 0.12 \mathrm{~cm}$, respectively. Furthermore, the percentage of leaf production per explants in CCR and CCY from axillary shoot bud explants was also higher compared to apical shoot bud explants. These results demonstrated that combination of cytokinin and auxin can give significant effects on shoot induction from apical and axillary shoot bud explants in both Calathea sp. Podwyszyńska [5] reported the establishment of optimum shoot multiplication of $C$. ornate Koern on MS medium supplemented with $2.5 \mathrm{mg} / \mathrm{L}$ BAP and $2.5 \mathrm{mg} / \mathrm{L}$ Kinetin. Different results were obtained in other Marantaceae plants as in multiple shoot induction of Maranta leuconeura cv. Kerchoviana was achieved by culturing the shoot tip explants on MS medium supplemented with $5 \mathrm{mg} / \mathrm{L}$ BAP [6] or when the lateral buds were cultured on Linsmaier and Skoog medium supplemented with $0.2 \mathrm{mg} / \mathrm{L}$ BAP [3]. Present study showed that further increase of BAP concentration will reduce the number of shoots induction and can cause necrosis (result not presented), indicating an adverse effect of plant growth regulators beyond the optimal concentration [20]. Higher concentration of cytokinin beyond the optimum levels was also reported to cause necrosis and reduction in shoot formation during in vitro multiplication of Musa sp. [21, 22]. Shoot organogenesis and multiple shoots induction by using various concentrations of BAP and NAA had been reported in several micropropagations of ornamental rhizomatic plants like Alpinia purpurata [23], Costus pictus D. Don [24], Heliconia psittacorum [9], and Musa beccarii [25]. The overall results in the present study showed that the using of axillary shoot bud explants in production and development of new shoots was more effective compared to the using of apical shoot bud explants.

4.4. Effects of Apex Damage to Induce Microshoots Formation. Stimulation of microshoots was obtained through elimination of apical dominance by shoot incision after 12 weeks culture (Table 5). Two types of incision were applied in this method to determine the effects on the microshoots production. Based on the results, microshoots were highly produced from the shoot bud that was longitudinally incised prior to culture. This result revealed that this method can be applied in mass propagation in order to increase the multiplication rate. Similar technique was used in stimulation of shoot branching in Strelitzia sp. [26] and Calathea ornata [5]. The excision of an apex is important for mass propagation of valuable ornamental plants with a naturally low rate of multiplication like Strelitzia sp. and Calathea sp. Cronauer and Krikorian [27] also reported the similar findings in induction of multiple shoots of two dessert banana clones and two plantain clones through excision of shoot tips. This phenomenon had been discussed precisely by Shimizu-Sato et al. [28] as it was found that cytokinin will be induced by decapitation of the shoot apex and stimulate axillary bud outgrowth.

4.5. Production of High Quality Plantlets through Addition of Glutamine and Activated Charcoal. This study was carried out to reduce necrosis problems presence in the previous culture through addition of glutamine, activated charcoal, or their combinations. Figure 4 and Table 7 show the stages of shoot development and the results obtained on leaf pigment concentration after three months of culture, respectively. Three types of leaf pigments were evaluated in this study, which are chlorophyll a, chlorophyll b, and carotenoid. Results show that the chlorophyll concentration in the leaf 


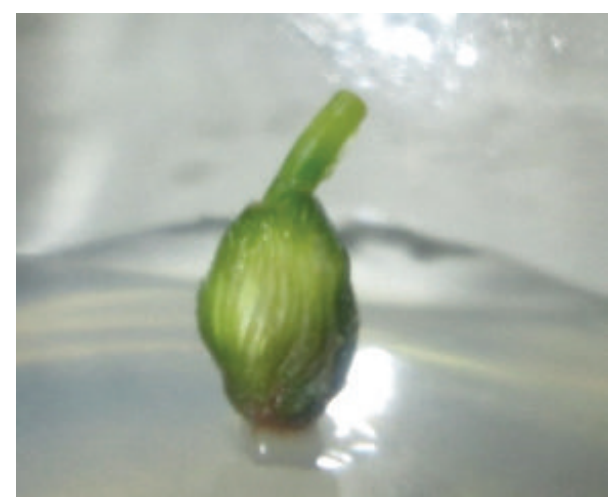

(a)

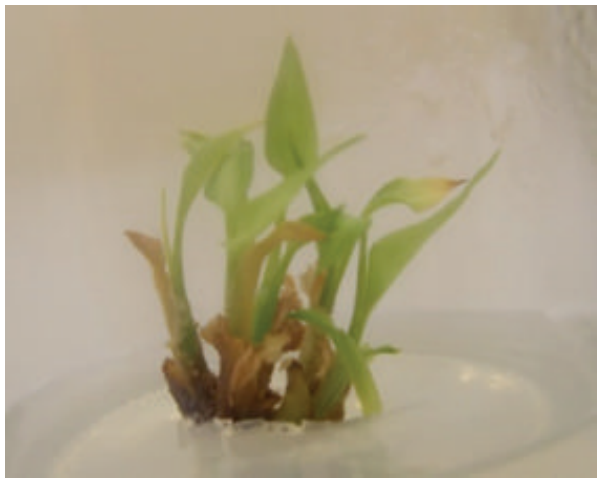

(c)

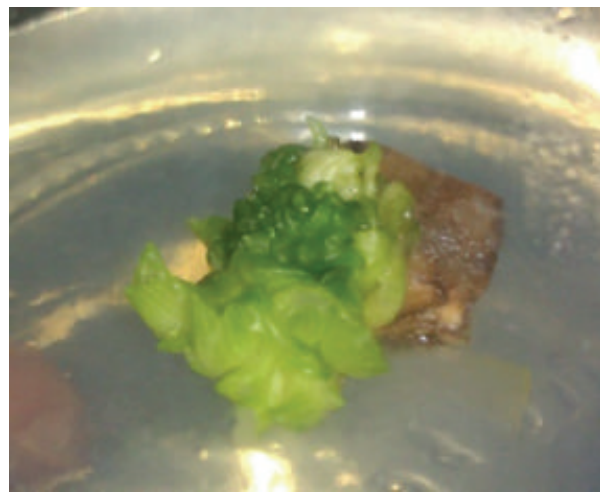

(e)

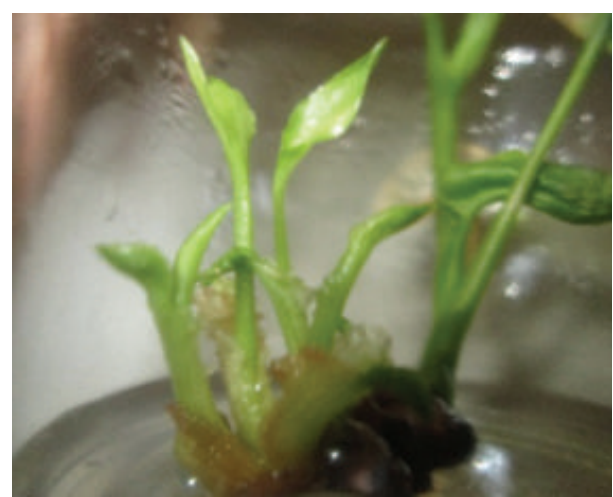

(b)

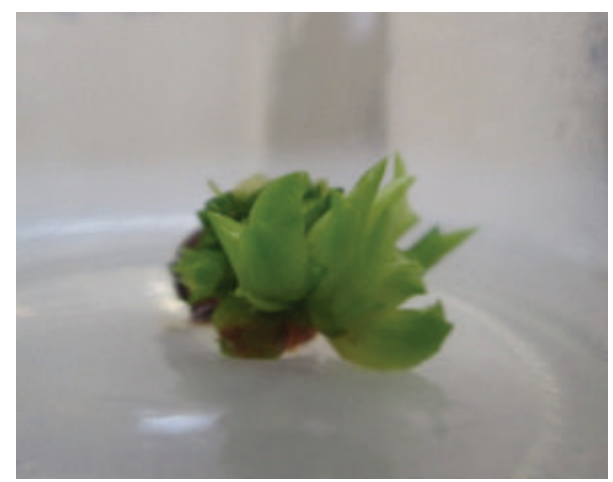

(d)

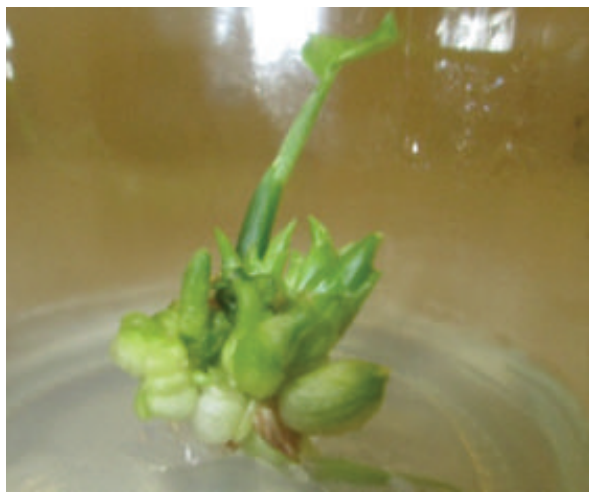

(f)

FiguRE 3: Effects of medium solidification and apex damage. (a) Swollenness of explant in media with 3 g/L plant agar. (b) Leaves show vitrification problem in media with $3 \mathrm{~g} / \mathrm{L}$ plant agar, (c) regenerated shoots with necrotic leaves in media with $8 \mathrm{~g} / \mathrm{L}$ plant agar. (d), (e), and (f) Induction of microshoots through elimination of apical dominance.

samples was varied depending on concentrations of glutamine and activated charcoal enriched in the medium. Addition of activated charcoal in MS medium was the most effective for production of shoots with dark green leaf and containing high concentration of chlorophyll pigments. However, the percentage of necrotic leaves was proportionally increased with the increasing of activated charcoal concentration. Multiplication medium fortified with glutamine produced shoots with light green leaf (Figure 4(c)) and containing low concentration of chlorophyll pigments and shows the lowest percentage of necrotic leaf. This result revealed that exogenous amino acid from glutamine serves as nitrogen source for the synthesis of protein [29] which is important to reduce necrosis effect on the leaf. In addition, Zouine and Hadrami [30] reported that exogenous supply of glutamine can possibly increase soluble storage protein in embryogenic cells of date palm suspension culture. Based on the overall result, the high quality in vitro plantlets with dark green leaf and low percentage of necrotic leaf were observed on multiplication medium fortified with $1.0 \mathrm{mg} / \mathrm{L}$ activated charcoal (3510 1C), (Table 7). Activated charcoal plays an important role in in vitro morphogenesis due to its irreversible adsorption of inhibitory compounds in the culture medium and substantially decreasing the toxic metabolites, 


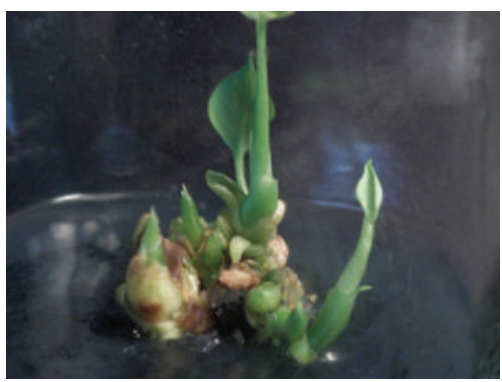

(a)

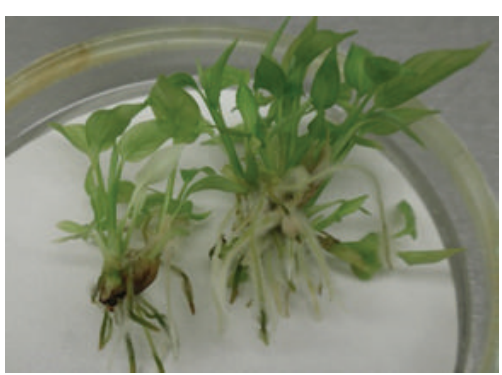

(d)

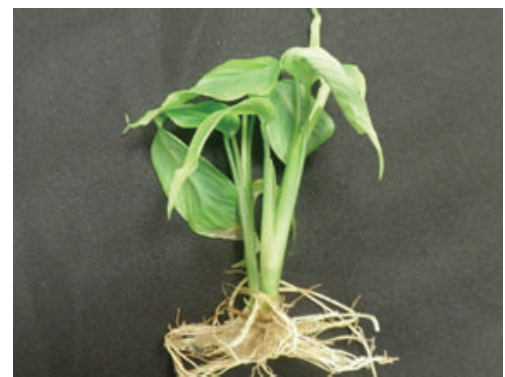

(g)

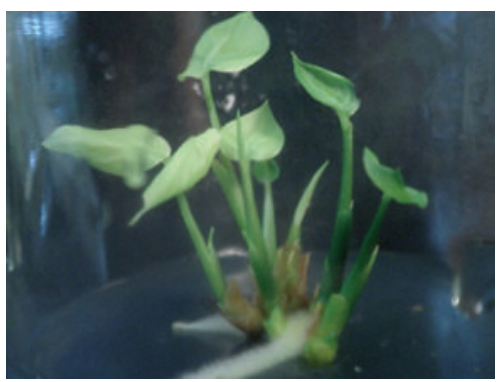

(b)

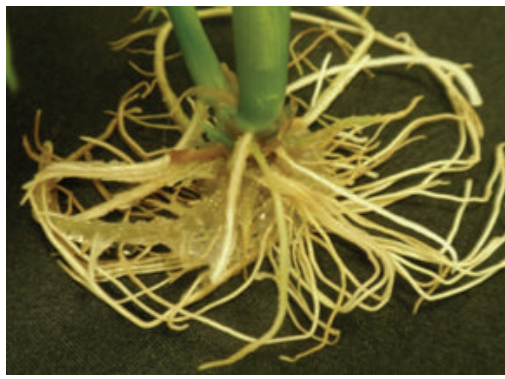

(e)

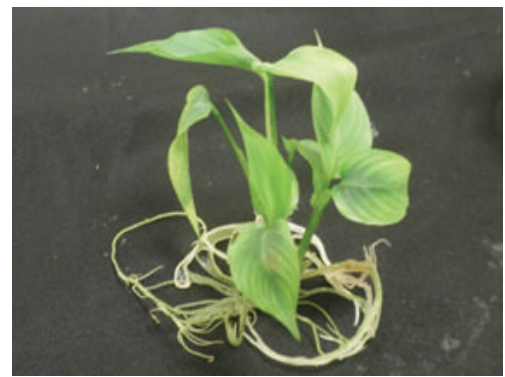

(h)

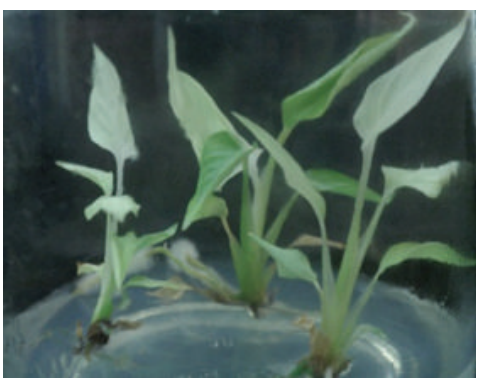

(c)

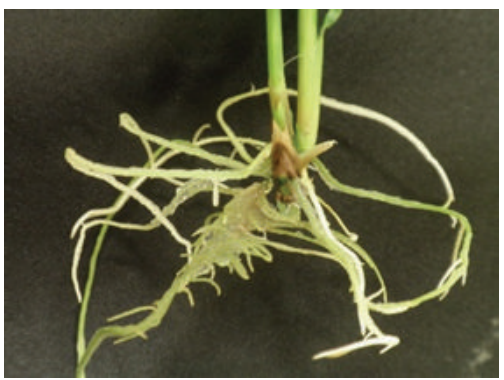

(f)

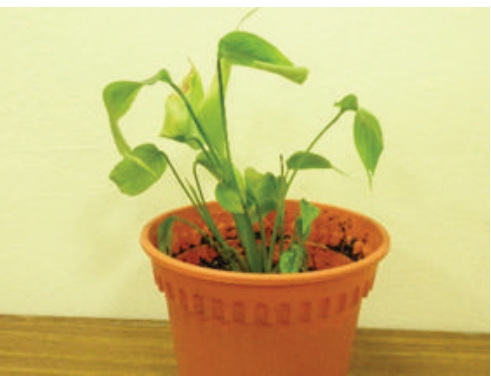

(i)

FIGURE 4: Development of high quality plantlet from shoot bud explants of Calathea crotalifera on multiplication media (MS medium with $3.5 \mathrm{mg} / \mathrm{L} \mathrm{BAP}$ and $1.0 \mathrm{mg} / \mathrm{L} \mathrm{NAA}$ ) and rooting media (MS medium with $1.0 \mathrm{mg} / \mathrm{L} \mathrm{NAA}$ ). (a) Induction of microshoots from incised shoot bud explants. (b) High quality plantlets with dark green leaves in multiplication medium supplemented with $1 \mathrm{~g} / \mathrm{L}$ activated charcoal. (c) Plantlets with light green leaves without necrosis problem on multiplication medium supplemented with 1 g/L L-glutamine. (d) Plantlets with high multiple shoots induction. (e) Induction of healthy root in rooting media supplemented with 1.0 mg/L NAA. (f) Roots induction on rooting media supplemented with $1.0 \mathrm{mg} / \mathrm{L}$ IBA. (g) and (h) Healthy plantlets ready to be acclimatized. (i) Development of successfully acclimatized plantlets.

phenolic exudation, and brown exudate accumulation, which also can promote growth and adsorption of vitamins, metal ions, and plant growth regulators, including gaseous ethylene [31]. Activated charcoal had been used to reduce explant browning problem in shoot tip culture for cryopreservation protocols in Rubus idaeus [32] at concentration of $0.25 \mathrm{~g} / \mathrm{L}$ fortified in MS medium. The explant browning also could be overcome by growing embryos of Dipterocarpus alatus and $D$. intricatus initially on a filter paper bridge in liquid medium with activated charcoal to absorb the oxidized phenolic compounds [33]. Figures 3(d), 3(e), and 3(f) show the induction of multiple shoots and rapid shoot elongation from the incised shoot buds in $35101 \mathrm{C}$ medium. The similar observations on induction and elongation of shoots have been reported in micropropagation studies such as cashew [34], eucalyptus [35], lilly [36], cotton [37], and yam [38]. Roots were also produced from the two to three months old plantlet of CCY and CCR cultured in the 3510 1C medium without transferring in the rooting medium (Figure 4(b)). Several studies have demonstrated that addition of activated charcoal alone or combined with auxin can promote roots induction from the mature in vitro plantlets [39-43]. Apart from that, according to Eymar et al. [44], activated charcoal also can give significant effect on in vitro nitrogen uptake in Lagerstroemia indica which demonstrated that the explants grown in medium with activated charcoal were capable of taking up both $\mathrm{NO}^{3-}$ and $\mathrm{NH}^{4+}$. Similar results were showed in the present study where the multiplication 


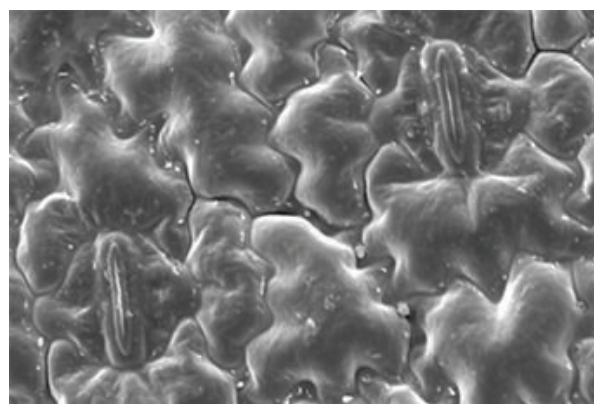

(a)

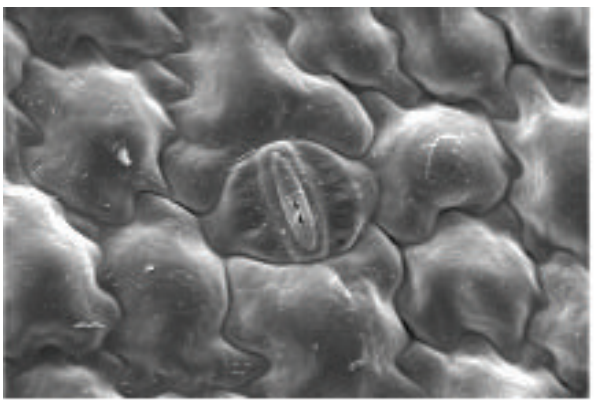

(c)

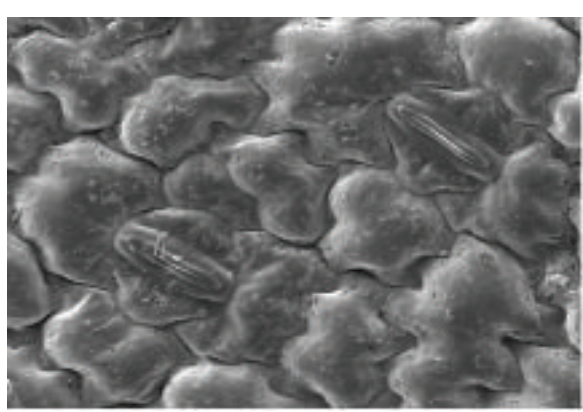

(b)

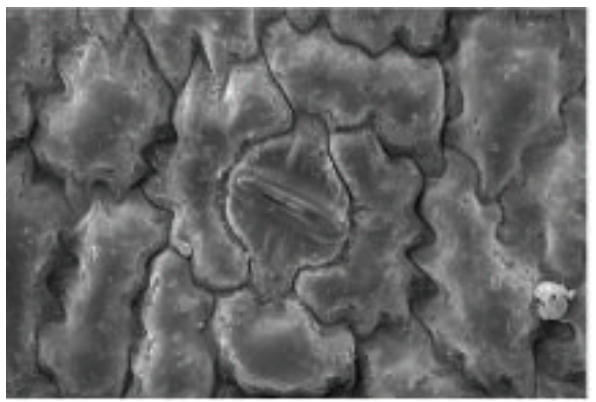

(d)

FIGURE 5: Scanning electron micrograph showing abaxial (a) and adaxial (c) surfaces of in vitro leaves of plantlet of Calathea crotalifera, abaxial (b) and adaxial (d) surfaces of leaves from in vivo (acclimatized) plant.

medium fortified with $1 \mathrm{~g} / \mathrm{L}$ glutamine and $1 \mathrm{~g} / \mathrm{L}$ activated charcoal (3510 G1C) produced high quality of plantlets as in 3510 1C medium (Table 7).

4.6. Root Induction. Based on results in Table 8, interaction of type and hormone concentration had significant relation with length, diameter, and number of roots. In general, roots were induced after three weeks of culture. Root number in both rooting media with NAA and IBA, respectively, was increased as the concentration of the auxin increased and started to decline when the concentration was higher than $1.0 \mathrm{mg} / \mathrm{L}$. Media with low concentration of auxin produced longer roots with small size in diameter. This result demonstrates that the plantlets could be rooted in both types of auxins but the highest number of roots was produced in MS medium supplemented with $1.0 \mathrm{mg} / \mathrm{L}$ NAA. Plantlet that cultured in media fortified with several concentrations of NAA produced high quality of roots in terms of number of roots, root length, and root diameter (Figure 4(e)). Similar results were reported by Hamad et al. [45] where media enriched with $1.0 \mathrm{mg} / \mathrm{L}$ NAA were the best media for induction of adventitious roots in pineapple and produced tallest plantlets with high number of roots per shoot. Raihana et al. [46] also demonstrated that MS medium supplemented with $1.0 \mathrm{mg} / \mathrm{L}$ NAA gave the highest root number in micropropagation of Curcuma mangga from rhizome bud where the increasing of NAA could suppress the production of root. However, Loc [47] and Yusuf et al. [13] reported that MS medium supplemented with $2.0 \mathrm{mg} / \mathrm{L}$ NAA could enhance roots induction in Curcuma zedoaria and Boesenbergia rotunda, respectively. Several studies demonstrated that most of the micropropagated rhizomatic plants can produce roots in MS medium devoid of auxin with or without addition of activated charcoal like Musa sp. [42, 48, 49], Curcuma sp. [50], Zingiber sp. [51], and Heliconia sp. [9]. The study suggested that these results might be due to the fact that some of rhizomatic plants can produce sufficient amount of auxin endogenously to initiate root induction.

\subsection{Micromorphological Development of Leaf in Acclimatized} Plantlets. The most crucial phase in micropropagation study is acclimatization of complete in vitro plantlets to the natural environment. Healthy plantlets taken out from the in vitro condition usually produced leaves with low epicuticular wax and with ineffective control of stomatal function [52]. These phenomena promote water loss through transpiration when the plantlets are transferred to the soil. In the present study, high quality of in vitro plantlets of $C$. crotalifera was successfully acclimatized with $75 \%$ of plantlet survival after four weeks of transfer (Figure 4(i)). In general, there were no morphological differences in the vegetative characters between in vivo and in vitro plant of $C$. crotalifera except for the sizes and texture of leaves. The texture of in vitro leaves surface was membranous while in vivo leaves were coriaceous due to the presence of thick cuticle layer with the presence of wax on in vivo leaves and absence of it on in vitro leaves as shown in Figure 5 under scanning electron microscope. Based on this micromorphological study, the acclimatized plantlets were well developed to adapt with the natural environment since they were exposed to the sun. The presence and thickness of the cuticle is dictated by environmental factor including sunlight and can be an 
TABLE 5: Effects of apex damage on production of microshoots in C. crotalifera (CCR and CCY).

\begin{tabular}{|c|c|c|c|c|c|c|}
\hline \multirow{2}{*}{ Apex damage } & \multicolumn{2}{|c|}{ Shoot production (\%) } & \multicolumn{2}{|c|}{ Number of microshoots } & \multicolumn{2}{|c|}{ Height of shoot $(\mathrm{cm})$} \\
\hline & CCY & CCR & CCY & CCR & CCY & CCR \\
\hline Longitudinal section & 100.0 & 100.0 & $8.0 \pm 0.9$ & $8.7 \pm 0.8$ & $4.0 \pm 0.5$ & $3.9 \pm 0.3$ \\
\hline Cross section & 50.0 & 50.0 & $1.0 \pm 0.3$ & $0.9 \pm 0.3$ & $0.7 \pm 0.1$ & $0.5 \pm 0.1$ \\
\hline
\end{tabular}

TABLE 6: Modification of multiplication media with different concentrations of activated charcoal and glutamine.

\begin{tabular}{ll}
\hline Media & Treatments \\
\hline 3510 & $\mathrm{MS}+3.5 \mathrm{mg} / \mathrm{L} \mathrm{BAP}+1.0 \mathrm{mg} / \mathrm{L} \mathrm{NAA}$ (control) \\
MSC1 & $\mathrm{MS}+1.0 \mathrm{~g} / \mathrm{L}$ activated charcoal \\
MSC2 & $\mathrm{MS}+2.0 \mathrm{~g} / \mathrm{L}$ activated charcoal \\
MSC3 & $\mathrm{MS}+3.0 \mathrm{~g} / \mathrm{L}$ activated charcoal \\
$3510 \mathrm{G} 03$ & $\mathrm{MS}+3.5 \mathrm{mg} / \mathrm{L} \mathrm{BAP}+1.0 \mathrm{mg} / \mathrm{L} \mathrm{NAA}+0.3 \mathrm{~g} / \mathrm{L}$ glutamine \\
$3510 \mathrm{G} 05$ & $\mathrm{MS}+3.5 \mathrm{mg} / \mathrm{L} \mathrm{BAP}+1.0 \mathrm{mg} / \mathrm{L} \mathrm{NAA}+0.5 \mathrm{~g} / \mathrm{L}$ glutamine \\
$3510 \mathrm{G} 10$ & $\mathrm{MS}+3.5 \mathrm{mg} / \mathrm{L} \mathrm{BAP}+1.0 \mathrm{mg} / \mathrm{L} \mathrm{NAA}+1.0 \mathrm{~g} / \mathrm{L}$ glutamine \\
$3510 \mathrm{G} 20$ & $\mathrm{MS}+3.5 \mathrm{mg} / \mathrm{L}$ BAP $+1.0 \mathrm{mg} / \mathrm{L} \mathrm{NAA}+2.0 \mathrm{~g} / \mathrm{L}$ glutamine \\
$3510 \mathrm{CC}$ & $\mathrm{MS}+3.5 \mathrm{mg} / \mathrm{L}$ BAP $+1.0 \mathrm{mg} / \mathrm{L} \mathrm{NAA}+1.0 \mathrm{~g} / \mathrm{L}$ activated charcoal \\
$3510 \mathrm{G1C}$ & $\mathrm{MS}+3.5 \mathrm{mg} / \mathrm{L}$ BAP $+1.0 \mathrm{mg} / \mathrm{L} \mathrm{NAA}+1.0 \mathrm{~g} / \mathrm{L}$ activated charcoal $+1.0 \mathrm{~g} / \mathrm{L}$ glutamine \\
\hline
\end{tabular}

TABLE 7: Effects of activated charcoal and glutamine on concentration of leaf pigments in yellow C. crotalifera (CCY).

\begin{tabular}{lccc}
\hline Media & Chlorophyll a $(\mu \mathrm{g} / \mathrm{mL})$ & Chlorophyll b $(\mu \mathrm{g} / \mathrm{mL})$ & Carotenoid $(\mu \mathrm{g} / \mathrm{mL})$ \\
\hline 3510 & $10.873 \pm 0.256^{\mathrm{a}}$ & $11.194 \pm 0.069^{\mathrm{A}}$ & $4.695 \pm 0.073^{\mathrm{a}}$ \\
MSC1 & $20.386 \pm 1.349^{\mathrm{d}}$ & $13.801 \pm 0.508^{\mathrm{D}}$ & $7.050 \pm 0.596^{\mathrm{c}}$ \\
MSC2 & $17.030 \pm 0.702^{\mathrm{c}}$ & $12.713 \pm 0.165^{\mathrm{C}}$ & $6.274 \pm 0.225^{\mathrm{bc}}$ \\
MSC3 & $16.830 \pm 0.553^{\mathrm{c}}$ & $12.513 \pm 0.243^{\mathrm{BC}}$ & $6.074 \pm 0.175^{\mathrm{b}}$ \\
3510 G03 & $11.430 \pm 0.591^{\mathrm{a}}$ & $11.755 \pm 0.331^{\mathrm{ABC}}$ & $4.914 \pm 0.167^{\mathrm{a}}$ \\
3510 G05 & $11.687 \pm 0.728^{\mathrm{a}}$ & $11.389 \pm 0.160^{\mathrm{AB}}$ & $4.805 \pm 0.210^{\mathrm{a}}$ \\
3510 G10 & $14.056 \pm 0.131^{\mathrm{b}}$ & $11.882 \pm 0.085^{\mathrm{ABC}}$ & $5.535 \pm 0.052^{\mathrm{ab}}$ \\
3510 G20 & $14.016 \pm 0.120^{\mathrm{b}}$ & $11.662 \pm 0.175^{\mathrm{ABC}}$ & $5.315 \pm 0.173^{\mathrm{ab}}$ \\
$35101 C$ & $21.520 \pm 1.116^{\mathrm{d}}$ & $15.025 \pm 0.766^{\mathrm{E}}$ & $7.990 \pm 0.536^{\mathrm{d}}$ \\
3510 G1C & $22.380 \pm 0.839^{\mathrm{d}}$ & $15.825 \pm 0.492^{\mathrm{E}}$ & $8.190 \pm 0.433^{\mathrm{d}}$ \\
\hline
\end{tabular}

Mean \pm SE, $n=10$. Different letters indicate significant differences between media at $P=0.05$.

TABLE 8: Effects of auxin on roots induction in yellow C. crotalifera (CCY).

\begin{tabular}{lcccc}
\hline NAA $(\mathrm{mg} / \mathrm{L})$ & IBA $(\mathrm{mg} / \mathrm{L})$ & Number of roots & Length of root $(\mathrm{cm})$ & Diameter of root $(\mathrm{cm})$ \\
\hline 0.00 & 0.00 & $2.60 \pm 0.40^{\mathrm{ab}}$ & $4.26 \pm 0.31^{\mathrm{AB}}$ & $0.15 \pm 0.01^{\mathrm{cd}}$ \\
0.10 & - & $2.80 \pm 0.37^{\mathrm{ab}}$ & $5.94 \pm 0.63^{\mathrm{BC}}$ & $0.15 \pm 0.01^{\mathrm{cd}}$ \\
0.50 & - & $3.60 \pm 0.24^{\mathrm{bc}}$ & $7.02 \pm 0.28^{\mathrm{CD}}$ & $0.18 \pm 0.01^{\mathrm{de}}$ \\
1.00 & - & $6.40 \pm 0.24^{\mathrm{d}}$ & $2.84 \pm 0.12^{\mathrm{A}}$ & $0.20 \pm 0.01^{\mathrm{e}}$ \\
1.50 & - & $4.00 \pm 0.32^{\mathrm{c}}$ & $2.91 \pm 0.39^{\mathrm{A}}$ & $0.20 \pm 0.01^{\mathrm{e}}$ \\
- & 0.10 & $2.00 \pm 0.32^{\mathrm{a}}$ & $7.00 \pm 1.17^{\mathrm{CD}}$ & $0.09 \pm 0.01^{\mathrm{a}}$ \\
- & 0.50 & $1.80 \pm 0.20^{\mathrm{a}}$ & $8.24 \pm 0.26^{\mathrm{D}}$ & $0.11 \pm 0.04^{\mathrm{ab}}$ \\
- & 1.00 & $3.20 \pm 0.37^{\mathrm{bc}}$ & $5.32 \pm 0.86^{\mathrm{BC}}$ & $0.13 \pm 0.01^{\mathrm{bc}}$ \\
- & 1.50 & $2.80 \pm 0.37^{\mathrm{ab}}$ & $5.20 \pm 0.73^{\mathrm{BC}}$ & $0.13 \pm 0.01^{\mathrm{bc}}$ \\
\hline
\end{tabular}

Mean \pm SE, $n=10$. Different letters indicate significant differences between media at $P=0.05$.

indicator for climate and habitat [53]. The difference of cuticle thickness between in vitro and in vivo leaves has been reported in acclimatization of micropropagated of Murraya paniculata plantlets [54]. The leaf lamina of in vitro and in vivo of $C$. crotalifera also showed little differences on anatomical characters since both leaves were hypostomatic. The mean number of stomata was higher on the abaxial surface compared to adaxial surface of the leaves (Table 9). This anatomical characteristic was also found on C. orbifolia (Linden) leaves as reported by Yang and Yeh [1]. 
TABLE 9: Stomata morphology of in vitro and acclimatized (in vivo) plantlets of yellow C. crotalifera (CCY) under scanning electron microscope.

\begin{tabular}{lcccc}
\hline \multirow{2}{*}{ Physiology } & \multicolumn{2}{c}{ Adaxial surface } & \multicolumn{2}{c}{ Abaxial surface } \\
& In vitro & In vivo & In vitro & In vivo \\
\hline Mean number stomata $\left(\right.$ per $\left.100 \mathrm{~mm}^{2}\right)$ & $5.75 \pm 1.25$ & $6.50 \pm 0.50$ & $20.25 \pm 2.25$ & $22.00 \pm 2.11$ \\
Length $(\mu \mathrm{m})$ & $27.65 \pm 1.00$ & $26.18 \pm 0.72$ & $25.95 \pm 0.70$ & $24.28 \pm 0.82$ \\
Width $(\mu \mathrm{m})$ & $11.15 \pm 0.26$ & $9.73 \pm 0.18$ & $9.39 \pm 0.49$ & $8.71 \pm 0.13$ \\
\hline
\end{tabular}

\section{Conclusion}

Sterile explants from shoot buds of Calathea crotalifera (yellow and red bract) could be established using combination of $30 \% \mathrm{NaOCl}$ (15 minutes), $70 \%$ ethanol (1 minute), and $0.3 \% \mathrm{HgCl}_{2}$ (10 minutes). This study indicates that rapid shoot induction has been obtained from axillary shoot bud explants cultured in the MS medium supplemented with $3.5 \mathrm{mg} / \mathrm{L}$ BAP and $1.0 \mathrm{mg} / \mathrm{L}$ NAA, with $6 \mathrm{~g} / \mathrm{L}$ of plant agar. Microshoots were highly produced from the shoot bud that was longitudinally incised prior to culture in the multiplication media due to the elimination of apical dominance. Production of high quality and healthy vigorous plantlets with low necrosis problem and vitrified shoots, and also with a higher chlorophyll content, have been established in the multiplication medium enriched with $1 \mathrm{~g} / \mathrm{L}$ activated charcoal and glutamine. The overall results demonstrated that this protocol is cost effective in terms of reduction of explants contamination percentage and production of multiple shoots in a short period. Microshoots and in vitro plantlets can be an important source of free disease planting material, ideally suited for germplasm exchange, transportation, and conservation of this exotic ornamental plant species.

\section{Conflict of Interests}

The authors declare that there is no conflict of interests regarding the publication of this paper.

\section{Acknowledgments}

The author acknowledged University of Malaya, Kuala Lumpur, Malaysia, for the financial support and research facilities. This research is funded by University of Malaya Postgraduate Research Fund (PV138/2012A).

\section{References}

[1] S. H. Yang and D. M. Yeh, "In vitro leaf anatomy, ex vitro photosynthetic behaviors and growth of Calathea orbifolia (Linden) Kennedy plants obtained from semi-solid medium and temporary immersion systems," Plant Cell, Tissue and Organ Culture, vol. 93, no. 2, pp. 201-207, 2008.

[2] R. E. Paull and T. Chantrachit, "Benzyladenine and the vase life of tropical ornamentals," Postharvest Biology and Technology, vol. 21, no. 3, pp. 303-310, 2001.

[3] S. Dunston and E. Sutter, "In vitro propagation of prayer plants," HortScience, vol. 19, pp. 511-512, 1984.

[4] A. van Mil and H. J. van Telgen, "Micropropagation of Calathea ornata," in Proceedings of the 7th International Congress on Plant
Tissue and Cell Culture, p. 117, Amsterdam, The Netherlands, 1990.

[5] M. Podwyszyńska, "Micropropagation of Calathea ornata Koern," Biologia Plantarum, vol. 39, no. 2, pp. 179-186, 1997.

[6] M. K. H. Ebrahim and I. A. Ibrahim, "Influence of medium solidification and $\mathrm{pH}$ value on in vitro propagation of Maranta leuconeura cv. Kerchoviana," Scientia Horticulturae, vol. 86, no. 3, pp. 211-221, 2000.

[7] T. C. M. Sundram, M. S. M. Annuar, and N. Khalid Norzulaani, "Optimization of culture condition for callus induction from shoot buds for establishment of rapid growing cell suspension cultures of Mango ginger (Curcuma mangga)," Australian Journal of Crop Science, vol. 6, no. 7, pp. 1139-1146, 2012.

[8] T. Murashige and K. Skoog, "A revised medium for rapid growth and bioassay with tobacco tissue culture," Physiologia Plantarum, vol. 15, pp. 473-497, 1962.

[9] M. J. Nathan, C. J. Goh, and P. P. Kumar, "In vitro propagation of Heliconia psittacorum bud culture," Hort Science, vol. 27, no. 5, pp. 450-452, 1992.

[10] A. Slatnar, M. Mikulic-Petkovsek, R. Veberic, F. Stampar, and V. Schmitzer, "Anthocyanin and chlorophyll content during poinsettia bract development," Scientia Horticulturae, vol. 150, pp. 142-145, 2013.

[11] A. R. Wellburn, "The spectral determination of chlorophyll-a and chlorophyll-b, as well as total carotenoids, using various solvents with spectrophotometers of different resolution," Journal of Plant Physiology, vol. 144, no. 3, pp. 307-313, 1994.

[12] T. Hosoki and Y. Sagawa, "Clonal propagation of ginger (Zingiber officinale Rosc.) through tissue culture," HortScience, vol. 12, pp. 451-452, 1997.

[13] N. A. Yusuf, M. S. M. Annuar, and N. Khalid, "Efficient propagation of an important medicinal plant boesenbergia rotunda by shoot derived callus," Journal of Medicinal Plants Research, vol. 5, no. 13, pp. 2629-2636, 2011.

[14] R. H. Smith, Plant Tissue Culture: Techniques and Experiments, Elsevier, New Delhi, India, 2nd edition, 2005.

[15] A. C. Cassells and R. F. Curry, "Oxidative stress and physiological, epigenetic and genetic variability in plant tissue culture: Implications for micropropagators and genetic engineers," Plant Cell, Tissue and Organ Culture, vol. 64, no. 2-3, pp. 145-157, 2001.

[16] O. Pérez-Tornero, J. Egea, E. Olmos, and L. Burgos, "Control of hyperhydricity in micropropagated apricot cultivars," In Vitro Cellular and Developmental Biology-Plant, vol. 37, no. 2, pp. 250-254, 2001.

[17] N. V. Kataeva, I. G. Alexandrova, R. G. Butenko, and E. V. Dragavtceva, "Effect of applied and internal hormones on vitrification and apical necrosis of different plants cultured in vitro," Plant Cell, Tissue and Organ Culture, vol. 27, no. 2, pp. 149-154, 1991.

[18] M. Pâques and P. Boxus, "Vitrification: review of literature," Acta Horticulturae, vol. 212, pp. 155-166, 1987. 
[19] J. P. Majada, M. I. Sierra, and R. Sánchez-Tamés, "Air exchange rate affects the in vitro developed leaf cuticle of carnation," Scientia Horticulturae, vol. 87, no. 1-2, pp. 121-130, 2001.

[20] A. Muhammad, H. Rashid, and I. Hussain, "Proliferation-rate effects of BAP and kinetin on banana (Musa spp. AAA group) "Basrai"', HortScience, vol. 42, no. 5, pp. 1253-1255, 2007.

[21] P. Madhulatha, M. Anbalagan, S. Jayachandran, and N. Sakthivel, "Influence of liquid pulse treatment with growth regulators on in vitro propagation of banana (Musa spp. AAA)," Plant Cell, Tissue and Organ Culture, vol. 76, no. 2, pp. 189-191, 2004.

[22] S. Wirakarnain, A. B. M. S. Hossain, and S. Chandran, "Plantlet production through development of competent multiple meristem cultures from male inflorescence of banana, Musa acuminta cv. "Pisang Mas" (AA)," American Journal of Biochemistry and Biotechnology, vol. 4, no. 4, pp. 325-328, 2008.

[23] R. D. Illg and R. T. Faria, "Micropropagation of Alpinia purpurata from inflorescence buds," Plant Cell, Tissue and Organ Culture, vol. 40, no. 2, pp. 183-185, 1995.

[24] K. Punyarani and J. G. Sharma, "Micropropagation and microrhizome indcution in Costus pictus D. Don using in vitro and ex vitro nodal segments as explants," Notulae Scientia Biologicae, vol. 4, no. 2, pp. 72-78, 2012.

[25] K. Rashid, A. Nezhadahmadi, R. O. Yasmin, N. I. Aina, S. Azhar, and S. Efzueni, "Micropropagation of ornamental plant Musa Beccarii through tissue culture technique using suckers and male buds as explants," Life Science Journal, vol. 9, no. 4, pp. 2046-2053, 2012.

[26] P. A. van de Pol and T. F. van Hell, "Vegetative propagation of Strelitzia reginae," Acta Horticulturae, vol. 226, pp. 581-586, 1988.

[27] S. S. Cronauer and A. D. Krikorian, "Multiplication of Musa from excised stem tips," Annals of Botany, vol. 53, no. 3, pp. 321328, 1984.

[28] S. Shimizu-Sato, M. Tanaka, and H. Mori, "Auxin-cytokinin interactions in the control of shoot branching," Plant Molecular Biology, vol. 69, no. 4, pp. 429-435, 2009.

[29] C. Stasolla, N. Loukanina, H. Ashihara, E. C. Yeung, and T. A. Thorpe, "Ascorbic acid changes the pattern of purine metabolism during germination of white spruce somatic embryos," Tree Physiology, vol. 21, no. 6, pp. 359-367, 2001.

[30] J. Zouine and I. El Hadrami, "Effect of 2,4-d, glutamine and BAP on embryogenic suspension culture of date palm (Phoenix dactylifera L.)," Scientia Horticulturae, vol. 112, no. 2, pp. 221226, 2007.

[31] T. D. Thomas, "The role of activated charcoal in plant tissue culture," Biotechnology Advances, vol. 26, no. 6, pp. 618-631, 2008.

[32] Q. Wang, J. Laamanen, M. Uosukainen, and J. P. T. Valkonen, "Cryopreservation of in vitro-grown shoot tips of raspberry (Rubus idaeus L.) by encapsulation-vitrification and encapsulation-dehydration," Plant Cell Reports, vol. 24, no. 5, pp. 280288, 2005.

[33] I. M. Linington, "In vitro propagation of Dipterocarpus alatus and Dipterocarpus intricatus," Plant Cell, Tissue and Organ Culture, vol. 27, no. 1, pp. 81-88, 1991.

[34] B. Boggetti, J. Jasik, and S. Mantell, "In vitro multiplication of cashew (Anacardium occidentale L.) using shoot node explants of glasshouse-raised plants," Plant Cell Reports, vol. 18, no. 6, pp. 456-461, 1999.

[35] L. P. Barrueto Cid, A. C. M. G. Machado, S. B. R. C. Carvalheira, and A. C. M. Brasileiro, "Plant regeneration from seedling explants of Eucalyptus grandis x E. urophylla," Plant Cell, Tissue and Organ Culture, vol. 56, no. 1, pp. 17-23, 1999.
[36] D. T. Nhut, B. V. Le, S. Fukai, M. Tanaka, and K. T. T. Van, "Effects of activated charcoal, explant size, explant position and sucrose concentration on plant and shoot regeneration of Lilium longiflorum via young stem culture," Plant Growth Regulation, vol. 33, no. 1, pp. 59-65, 2001.

[37] S. Hazra, A. V. Kulkarni, A. K. Banerjee et al., "A rapid and simple method for in vitro plant regeneration from split embryo axes of six cultivars of cotton," Biologia Plantarum, vol. 45, no. 2, pp. 317-319, 2002.

[38] M. Borges, W. Ceiro, S. Meneses et al., "Regeneration and multiplication of Dioscorea alata germplasm maintained in vitro," Plant Cell, Tissue and Organ Culture, vol. 76, no. 1, pp. 87-90, 2004.

[39] A. Barceló-Muñoz, C. L. Encina, E. Simón-Pérez, and F. PliegoAlfaro, "Micropropagation of adult avocado," Plant Cell, Tissue and Organ Culture, vol. 58, no. 1, pp. 11-17, 1999.

[40] A. Negash, K. Puite, J. Schaart, B. Visser, and F. Krens, "In vitro regeneration and micro-propagation of enset from Southwestern Ethiopia," Plant Cell, Tissue and Organ Culture, vol. 62, no. 2, pp. 153-158, 2000.

[41] A. Jemmali, N. Elloumi, C. Kevers, and J. Dommes, "Morphological and hormonal characterisation of strawberry vitroplants raised through axillary or stipular adventitious shooting," Plant Growth Regulation, vol. 38, no. 3, pp. 273-278, 2002.

[42] M. Jalil, N. Khalid, and R. Y. Othman, "Plant regeneration from embryogenic suspension cultures of Musa acuminata cv. Mas (AA)," Plant Cell, Tissue and Organ Culture, vol. 75, no. 3, pp. 209-214, 2003.

[43] A. Anu, K. N. Babu, and K. V. Peter, "Variations among somaclones and its seedling progeny in Capsicum annuum," Plant Cell, Tissue and Organ Culture, vol. 76, no. 3, pp. 261-267, 2004.

[44] E. Eymar, J. Alegre, M. Toribio, and D. López-Vela, "Effect of activated charcoal and 6-benzyladenine on in vitro nitrogen uptake by Lagerstroemia indica," Plant Cell, Tissue and Organ Culture, vol. 63, no. 1, pp. 57-65, 2000.

[45] A. H. M. Hamad, R. M. Taha, and S. Mohajer, "In vitro induction and proliferation of adventitious roots in pineapple (Ananas comosus L.) cultivars of smooth cayenne and morris," Australian Journal of Crop Science, vol. 7, no. 7, pp. 1038-1045, 2013.

[46] R. Raihana, Q. Z. Faridah, A. A. Julia, A. H. A. Abdelmageed, and M. A. Kadir, "In vitro culture of Curcuma mangga from rhizome bud," Journal of Medicinal Plant Research, vol. 5, no. 28, pp. 6418-6422, 2011.

[47] H. L. Nguyen, T. D. Doan, H. K. Tae, and S. Y. Moon, "Micropropagation of zedoary (Curcuma zedoaria Roscoe)-a valuable medicinal plant," Plant Cell, Tissue and Organ Culture, vol. 81, no. 1, pp. 119-122, 2005.

[48] W. Xiao, X. Huang, Y. Chen, X. Dai, and J. Zhao, "Plant regeneration from protoplasts of Musa acuminata cv. Mas (AA) via somatic embryogenesis," Plant Cell, Tissue and Organ Culture, vol. 90, no. 2, pp. 191-200, 2007.

[49] W. C. Wong, M. Jalil, M. Ong-Abdullah, R. Y. Othman, and N. Khalid, "Enhancement of banana plant regeneration by incorporating a liquid-based embryo development medium for embryogenic cell suspension," The Journal of Horticultural Science and Biotechnology, vol. 81, no. 3, pp. 385-390, 2006.

[50] N. D. Salvi, L. George, and S. Eapen, "Plant regeneration from leaf base callus of turmeric and random amplified polymorphic DNA analysis of regenerated plants," Plant Cell, Tissue and Organ Culture, vol. 66, no. 2, pp. 113-119, 2001.

[51] M. N. Hamirah, H. B. Sani, P. C. Boyce, and S. L. Sim, "Micropropagation of red ginger (Zingiber montanum koenig), a 
medicinal plant," Asia-Pacific Journal of Molecular Biology and Biotechnology, vol. 18, no. 1, pp. 127-130, 2010.

[52] M. Chithra, K. P. Martin, C. Sunandakumari, and P. V. Madhusoodanan, "Protocol for rapid propagation, and to overcome delayed rhizome formation in field established in vitro derived plantlets of Kaempferia galanga L.," Scientia Horticulturae, vol. 104, no. 1, pp. 113-120, 2005.

[53] H. P. Wilkinson, "Plant surface," in Anatomy of the Dicotyledons, C. R. Metcalfe and L. Chalk, Eds., vol. 1, pp. 97-162, Clarendon Press, Oxford, UK, 1979.

[54] R. M. Taha and N. W. Haron, "Some morphological and anatomical studies of leaves and flowers of Murraya paniculata (Jack) Linn. in vivo and in vitro," Pakistan Journal of Biological Sciences, vol. 11, no. 7, pp. 1021-1026, 2008. 

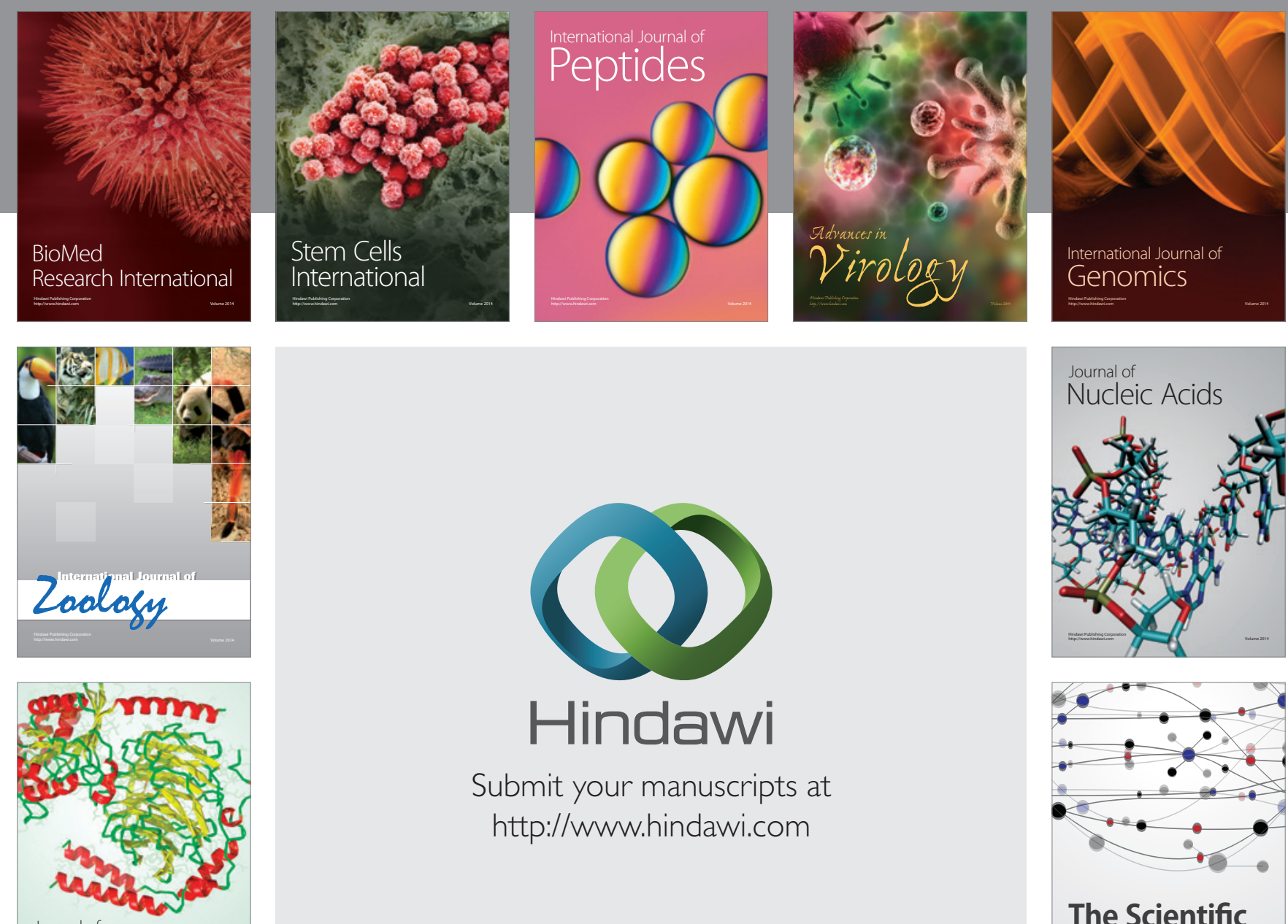

Submit your manuscripts at

http://www.hindawi.com

Journal of
Signal Transduction
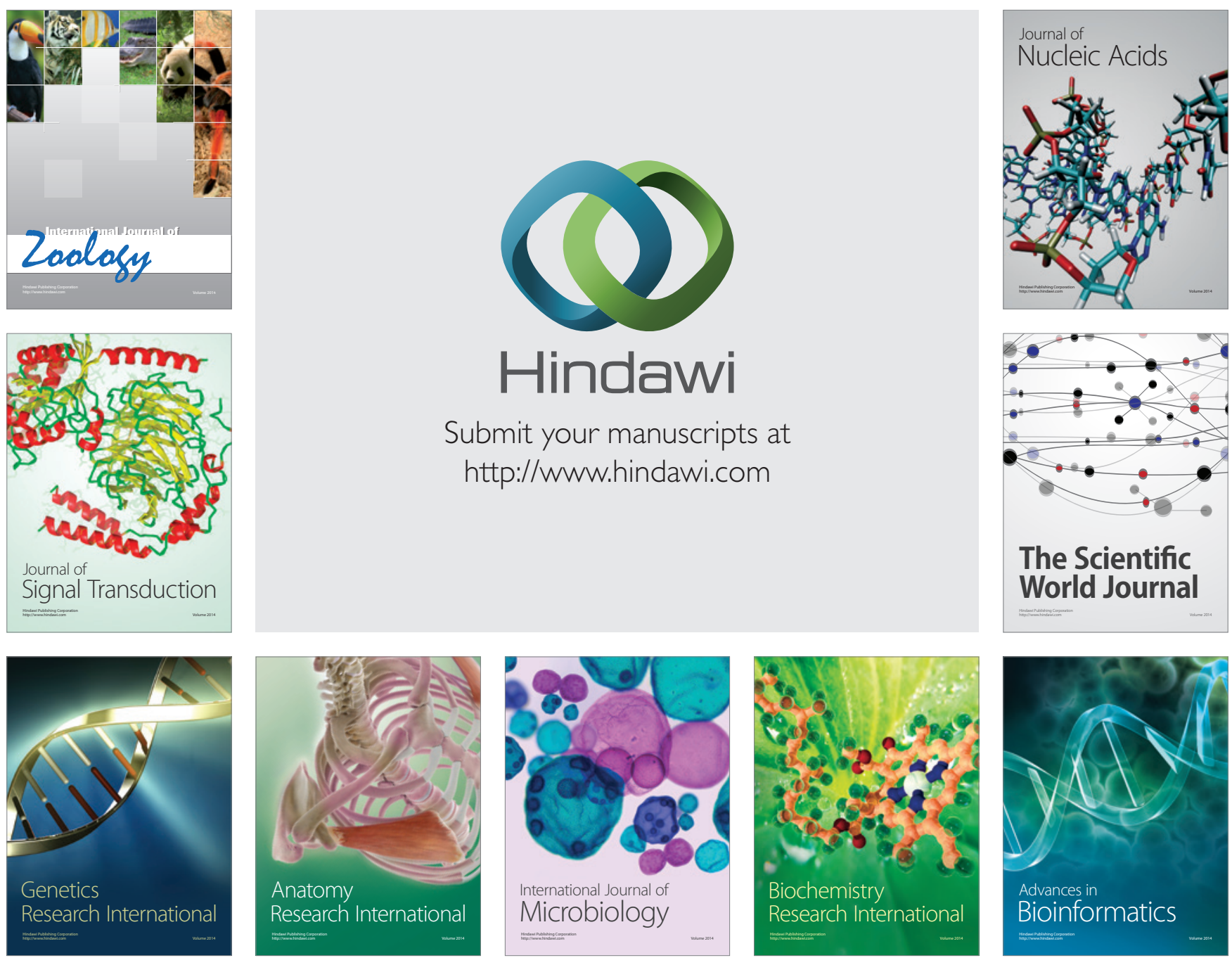

The Scientific World Journal
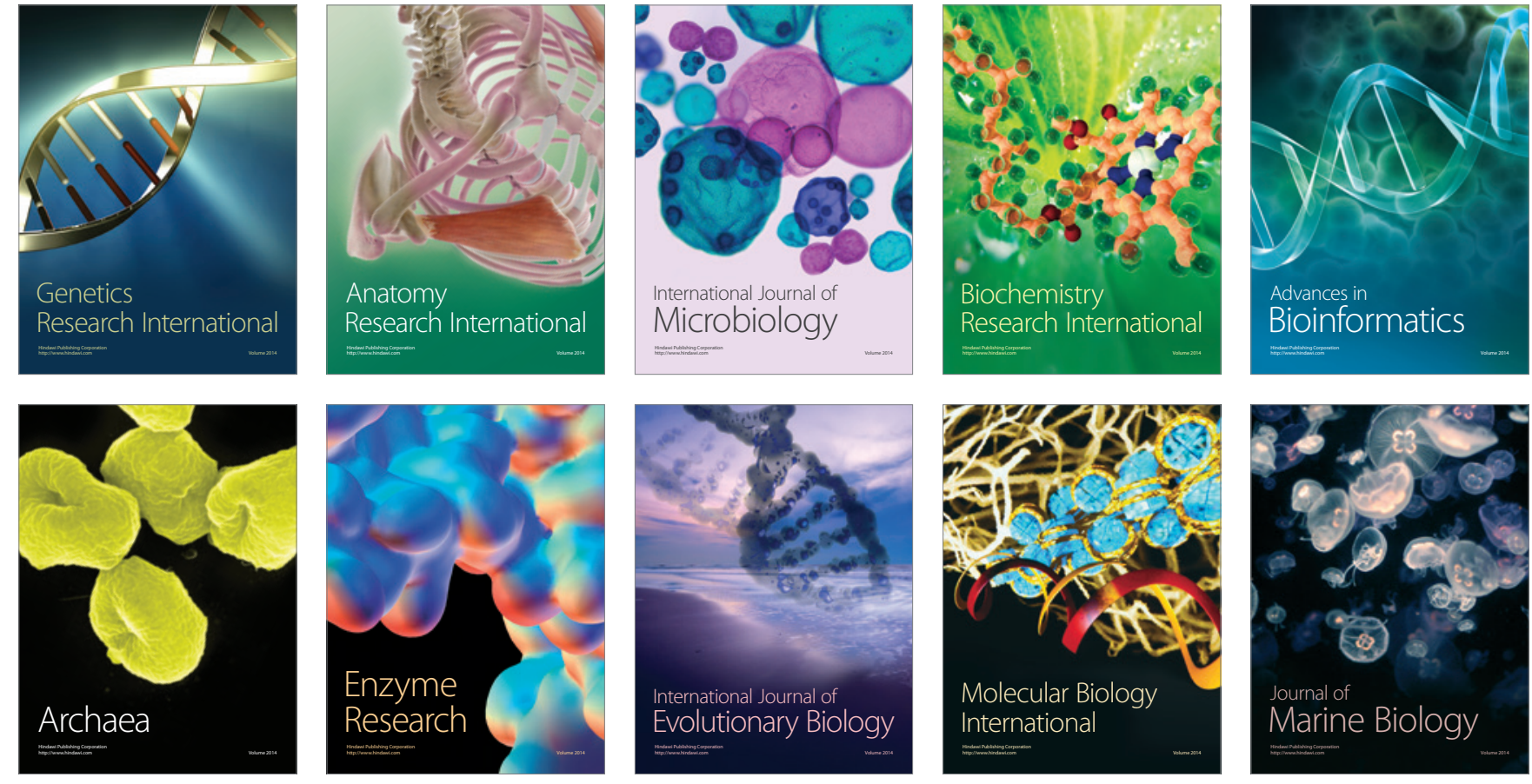